\title{
FAM83A wt Allele
}

National Cancer Institute

\section{Source}

National Cancer Institute. FAM83A wt Allele. NCI Thesaurus. Code C106099.

Human FAM83A wild-type allele is located in the vicinity of $8 \mathrm{q} 24.13$ and is approximately

$31 \mathrm{~kb}$ in length. This allele, which encodes protein FAM83A, may play a role in chemotherapy-resistant tumors. 